\title{
Heterogenous Weld of Heat Resistant Steel With Cobalt Alloy
}

\section{Marian Sigmund (0000-0002-6330-8788)}

FSI VUT Brno, Faculty of Mechanical Engineering, Institute of Manufacturing Technology, Department of Welding Technology and Surface Treatment, Technická 2896/2, 616 69, Brno, Czech Republic, E-mail: sigmund@fme.vutbr.cz

The article describes problems of welding heterogeneous welds be specific of heat resistant stainless steel X15CrNiSi20-25 with cobalt alloy Stellite 6. Heterogeneous welds are produced by GTAW (141 according to standard EN ISO 4063) welding method. The major goals of the experiment were performing preliminary welding specifications (pWPS) for a specific welded part. For appropriate welding qualification specification was necessary for this specific weldment set up proper parameters of mechanical testing.

Keywords: GTAW welding (method 141), Heterogeneous weld, pWPS - preliminary welding specification, Cobalt alloy.

\section{Introduction}

The problems with weldability of heterogeneous welds are solving by many areas of welding, hard surfacing, renovation welding, and surface treatment with the different industrial sectors. For example, in the nuclear or thermal energy sector, steel constructions, petrochemical sector (oil and gas) or chemical sector and for example also in the food industry and pharmacy. The case of this article answered the weldability of heterogeneous weld heat resistant steel with cobalt alloy on a specific part of flow drain bushing of Venturi tube. This specific part is part of flowmeters, limiting definitive openings, flow drain bushing largely supplied to the oil and gas sector. On this, the very incurred weld will be performed quality and mechanical testing and on its results will be recommended welding qualification specification. Fixation weld to fitting is performed by several variants, for example by filled weld directly to fitting or by the enclosure and resulting bushing welding.

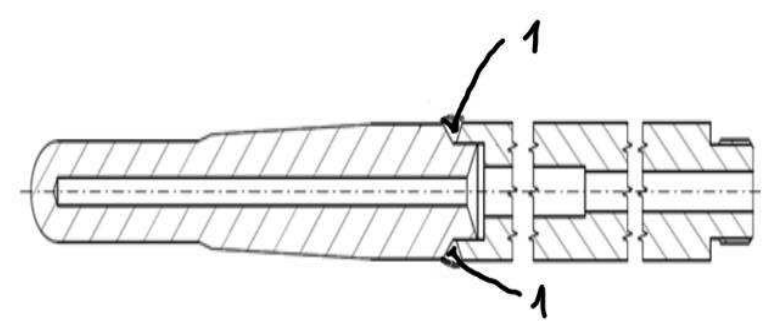

Fig. 1 Detail of experimental part

\section{Experimental part}

The experimental welded part is well for temperature measuring of fluent, liquid media in piping or fitting (Figure 1). That presents on one end closed pipe, that is welded from two heterogeneous alloys. Acts about heterogeneous weld (Figure 2). In places, where's a pipe in continuous contact with medium is used cobalt alloy (Stellite 6), with is welded cylindrical part with a straight-through hole from heat resistant stainless steel X15CrNiSi20-25. Both these single parts are constructional modified and machined to welding around „lock circuit weld" by GTAW welding method.

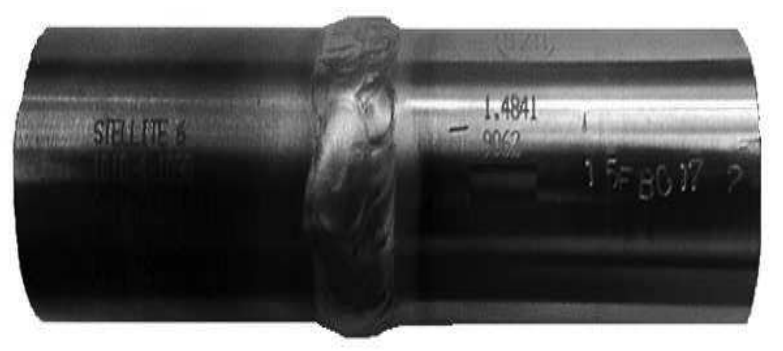

Fig. 2 Detail of heterogeneous weld

\section{Experiment}

The experimental part is welded from two heterogeneous materials with different chemical compositions and also mechanical values.

\subsection{Cobalt Alloy Stellite 6}

Cobalt alloy Stellite 6 (microstructure Figure 3) is a chromium-cobalt alloy compact of complex carbides, resistant to abrasion, mechanical damage, and chemical corrosion during very high temperatures [6]. This alloy has a very fine resistance to impact and erosive cavitation. Behind these, all the best characteristics are bound to the CoCr matrix. Stellite 6 is used mainly during welding valve seats and more exhaust parts. Chemical composition and mechanical properties are mentioned in following tables 1 and 2. 


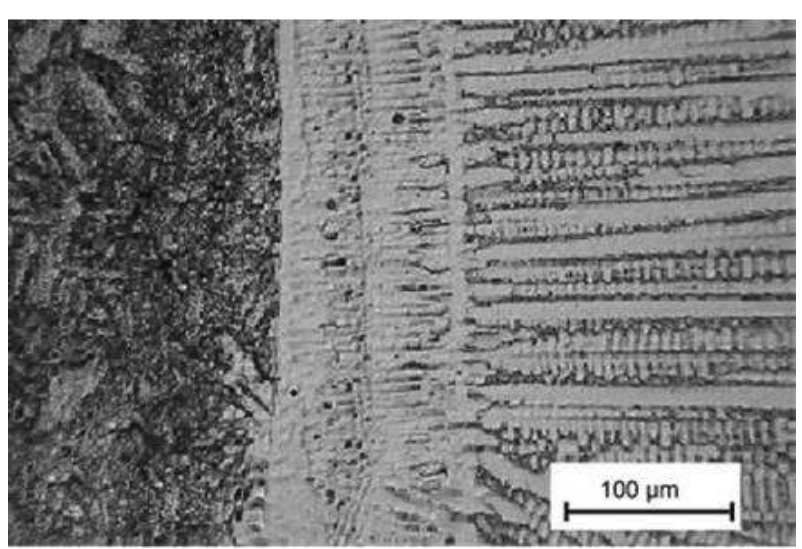

Fig. 3 Microstructure of Stellite 6

Tab. 1 Chemical composition of Stellite 6

\begin{tabular}{|c|c|c|c|c|c|}
\hline $\mathbf{C}$ & $\mathbf{C r}$ & $\mathbf{S i}$ & $\mathbf{W}$ & $\mathbf{F e}$ & $\mathbf{C o}$ \\
\hline 0.99 & 29.47 & 0.59 & 3.55 & 1.27 & Rest. \\
\hline $\mathbf{~ N i}$ & $\mathbf{M n}$ & $\mathbf{M o}$ & $\mathbf{P}$ & $\mathbf{S}$ & \\
\hline 2.76 & 1.21 & 1.35 & $<0.01$ & $<0.002$ & \\
\hline
\end{tabular}

Tab. 2 Mechanical properties during room temperature of Stellite 6

\begin{tabular}{|l|l|l|c|}
\hline \multicolumn{4}{|l|}{ Stellite 6} \\
\hline Yield stress & $\mathrm{Rp} 0,2$ & $\mathrm{MPa}$ & 750 \\
\hline Ultimate stress & $\mathrm{Rm}$ & $\mathrm{MPa}$ & 1260 \\
\hline Ductility & $\mathrm{A}$ & $\%$ & 3 to 5 \\
\hline Hardness & & $\mathrm{HV}$ & 380 to 490 \\
\hline
\end{tabular}

\subsection{Heat resistant stainless steel $\mathrm{X} 15 \mathrm{CrNiSi20-25}$}

A heat resistant stainless steel $\mathrm{X} 15 \mathrm{CrNiSi} 20-25$ is an austenitic chromium-nickel stainless steel (microstructure Figure 4) normally used for thermally stressed parts. Weldability of this stainless steel is guaranteed, but machinability is worse. During longterm exposition at temperature 600 to $900^{\circ} \mathrm{C}$ happens to embrittlement owing to 6 -phase. The exact chemical composition and mechanical properties of used stailess steel are in Tables 3 and 4.

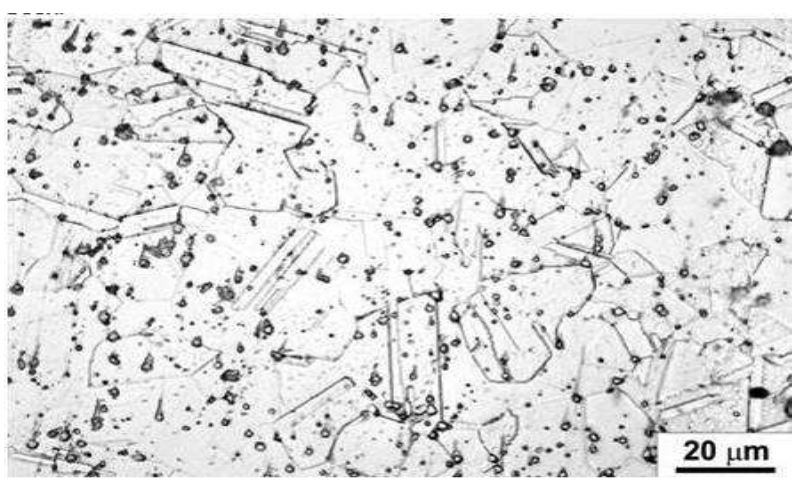

Fig. 4 Microstructure of Heat resistant stainless steel X15CrNiSi20-25

Tab. 3 Chemical composition of X15CrNiSi20-25

\begin{tabular}{|l|l|l|l|l|l|l|}
\hline $\mathbf{C}$ & $\mathbf{S i}$ & $\mathbf{M n}$ & $\mathbf{N i}$ & $\mathbf{C r}$ & $\mathbf{S}$ & $\mathbf{P}$ \\
\hline 0.03 & 2.1 & 1.5 & 20.5 & 24.4 & 0.001 & 0.023 \\
\hline
\end{tabular}

Tab. 4 Mechanical properties of X15CrNiSi20-25

\begin{tabular}{|l|l|l|c|}
\hline X15CrNiSi20-25 & \multicolumn{3}{|l|}{} \\
\hline Yield stress & $\mathrm{Rp}_{0,2}$ & $\mathrm{MPa}$ & 270 \\
\hline $\begin{array}{l}\text { Ultimate } \\
\text { stress }\end{array}$ & $\mathrm{Rm}$ & $\mathrm{MPa}$ & 570 \\
\hline Ductility & $\mathrm{A}$ & $\%$ & 56 \\
\hline Hardness & & $\mathrm{HV}$ & 163 \\
\hline
\end{tabular}

This steel has better constancy in a corrosion-resistant environment than ferritic chromium-nickel steels. It's good warm and cold formability and it is possible to use it for highly thermally and mechanically stressed parts. This material is normally used for furnace burner covers, burner, and thermocouple housing in a steam-boiler. Heat resistant stainless steels X15CrNiSi20-25 are supplied in a thermally modified state after solution annealing. After welding these steels are not post-weld heat treated. Predisposition to cracking and hot cracking of these steel is calculated from the formula [1]:

$$
\Delta H=-700 \cdot \mathrm{C}+17 \cdot \mathrm{Cr}-37 \cdot \mathrm{Ni}+29 \cdot \mathrm{Mo}+188 \quad[-],
$$

above $300^{\circ} \mathrm{C}$, especially for pressure vessels until temperatures $1200^{\circ} \mathrm{C}$. The chrome-nickel filler material isn't sensitive to hot cracking. Carbon diffusion during higher temperatures is a major part suppressed. This filler material is also resistant to thermal impact, is also corrosion resistant, and has low coefficient heat extensibility. During welding is as shielding gas used pure Argon or mixture Argon with Helium. With this filler material is possible to weld in all positions. Is supplied for GTAW welding in meter long GTAW rod with a diameter from $1.6 \mathrm{~mm}$ to $3.2 \mathrm{~mm}$. The chemical compositions and mechanical properties of $\mathrm{NiCr} 20 \mathrm{Mn} 3 \mathrm{Nb}$ filler material are mentioned in Table 5. 
Tab. 5 Chemical compositions and mechanical properties of filler material $\mathrm{NiCr} 20 \mathrm{Mn} 3 \mathrm{Nb}$

\begin{tabular}{|l|l|l|l|l|l|l|}
\hline \multicolumn{7}{|l|}{ Chemical compositions [hm. \%] } \\
\cline { 1 - 5 } C & Si & Mn & P & S & Cr & Ni \\
\hline 0.02 & $<0.1$ & 3.2 & 0.002 & 0.001 & 20.6 & 73.1 \\
\hline $\mathbf{C u}$ & $\mathbf{T i}$ & $\mathbf{N b}$ & $\mathbf{F e}$ & & & \\
\hline$<0.1$ & 0.3 & 2.4 & 0.2 & & & \\
\hline \multicolumn{7}{|l|}{ Mechanical properties [MPa] } \\
\hline Rm & \multicolumn{7}{|l|}{$\mathrm{Rp}_{0,2}$} & & & \\
\hline$>620$ & $>400$ & & & \\
\hline
\end{tabular}

\subsection{Sample preparation before welding}

The single parts were turned according to preproduction drawing and specification (weld bevel detail acc. Figure 5) for the next welding ,lock circuit weld". This weld bevel is used for welding cylindrical vessels and one-side welds. For this special weld design is a small requirement to be specific weld with half penetration of „lock circuit weld". Root gap of weld has size $1.5 \mathrm{~mm}$. The whole part was fixed to the fixture for welding [2].

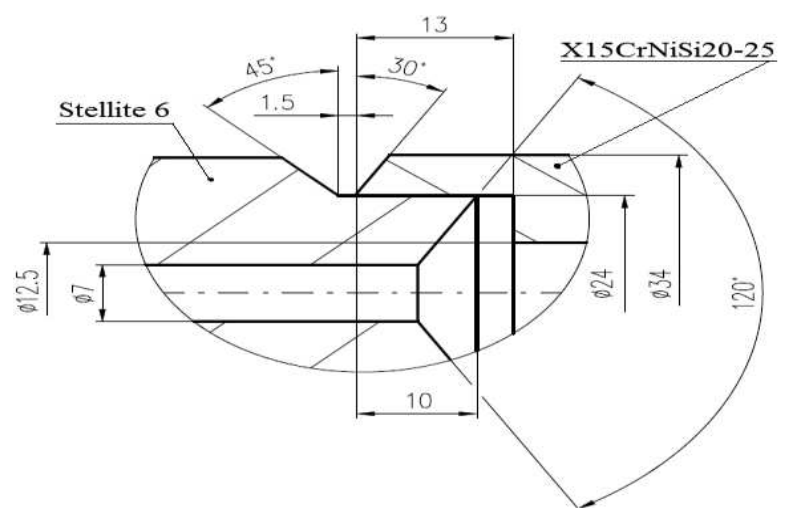

Fig.5 Detail of weld bevel [2]

\subsection{Preheating and interpass selection}

During welding austenitic corrosion-resistant stailess steel isn't recommended to use preheating, because add on heat input increases the danger of residual stress and deformation, hot cracking, sensation, and precipitation of the intermetallic phase. For this reason, were first suggested an interpass temperature of $400^{\circ} \mathrm{C}$ for corrosion and heat resistant stainless steel X15CrNiSi20-25. And from that temperature were a secondary set up preheating temperature for wole part that is about $100^{\circ} \mathrm{C}$ lower. Then [1]:

$$
T p=400-100=300\left[{ }^{\circ} \mathrm{C}\right]
$$

This preheating temperature is also proper for cobalt alloy Stellite 6.

\subsection{Sample welding}

According to pWPS were during turning by GTAW welding method welded two samples. Two seams were welded in position PA by six layers to a total thickness of $5.5 \mathrm{~mm}$. Welding parameters for each sample are mentioned in Tables 6 and 7. Welding current was constantly for sample No. $1 \mathrm{I}=133 \mathrm{~A}$ and for sample No. 2 $\mathrm{I}=134 \mathrm{~A}$. Shielding gas was used Argon 4,6, its classification I1 according to standard EN ISO 14175. Samples were welded by non-melted tungsten electrode WCe20 diameter $3.2 \mathrm{~mm}$ with classification according to standard EN ISO 6848. Preheating temperature and interpass was measured by a contact thermometer. After welding were both samples wrapt to the insulation and slowly cool in the wrap.

Tab. 5 Welding parameters of sample No.1

\begin{tabular}{|l|l|l|l|c|}
\hline Layer & $\begin{array}{l}\text { Dia. } \\
{[\mathbf{m m}]}\end{array}$ & Preheating $\left[{ }^{\circ} \mathbf{C}\right]$ & Interpass $\left[{ }^{\circ} \mathbf{C}\right]$ & $\begin{array}{c}\text { Voltage } \\
{[\mathbf{V}]}\end{array}$ \\
\hline 1st & 1.6 & 329 & - & $9.4-13.1$ \\
\hline 2nd & 2.4 & - & 338 & $9.6-13.4$ \\
\hline 3rd & 1.6 & - & 386 & $10.8-13.8$ \\
\hline 4st & 2.4 & - & 371 & $11-14.1$ \\
\hline $\mathbf{5 s t}$ & 2.4 & - & 388 & $11.3-13.9$ \\
\hline 6st & 1.6 & - & 374 & $10.9-13.7$ \\
\hline Layer & Dia. & Gas flow $[1 /$ min] & $\begin{array}{c}\text { Welding speed } \\
{[\mathbf{c m} / \mathbf{m i n}]}\end{array}$ & Heat input $[\mathbf{k J} / \mathbf{c m}]$ \\
\hline 1st & 1.6 & 10.9 & 9.2 & $4.6-6.9$ \\
\hline 2nd & 2.4 & 11.1 & 7.9 & $5.8-8.1$ \\
\hline 3rd & 1.6 & 11.1 & 10.5 & $4.9-6.3$ \\
\hline 4st & 2.4 & 11.1 & 9.5 & $5.6-7.1$ \\
\hline 5st & 2.4 & 11.1 & 9.4 & $5.8-7.1$ \\
\hline 6st & 1.6 & 11.1 & 9.0 & $5.8-7.3$ \\
\hline
\end{tabular}


Tab. 6 Welding parameters of sample No.2

\begin{tabular}{|l|c|c|c|c|}
\hline Layer & $\begin{array}{l}\text { Dia. } \\
{[\mathbf{m m}]}\end{array}$ & Preheating $\left[{ }^{\circ} \mathbf{C}\right]$ & Interpass [ $\left.{ }^{\circ} \mathbf{C}\right]$ & Voltage [V] \\
\hline 1st & 1.6 & 304 & - & $9.2-12.6$ \\
\hline 2nd & 2.4 & - & 353 & $9.2-13.1$ \\
\hline 3rd & 2.4 & - & 354 & $9.8-13.8$ \\
\hline 4st & 2.4 & - & 372 & $11.1-13.8$ \\
\hline 5st & 2.4 & - & 389 & $11.1-13.4$ \\
\hline 6st & 1.6 & - & 400 & $10.9-14.1$ \\
\hline Layer & Dia. & Gas flow [1/min] & $\begin{array}{c}\text { Welding speed } \\
{[\mathbf{c m} / \mathbf{m i n}]}\end{array}$ & Heat input $[\mathbf{k J} / \mathbf{c m}]$ \\
\hline 1st & 1.6 & 10.9 & 9.5 & $4.6-6.4$ \\
\hline 2nd & 2.4 & 11.1 & 7.1 & $6.2-8.8$ \\
\hline 3rd & 1.6 & 11.1 & 9.6 & $4.8-6.9$ \\
\hline 4st & 2.4 & 11.1 & 9.7 & $5.5-6.9$ \\
\hline 5st & 2.4 & 11.1 & 10.4 & $5.1-6.2$ \\
\hline 6st & 1.6 & 11.1 & 9.3 & $5.7-7.3$ \\
\hline
\end{tabular}

\section{Experiment evaluation}

After welding was performed non - destructive testing. Non-destructive testing has a purpose to find any weld imperfection, above all defects as cracks, porosities, and inclusions. After it was performing some metallographic and destructive testing to check macro and microstructure and mechanical properties of a welded heterogeneous weld.

\subsection{Visual and penetrant testing}

A samples were visually tested according to standards EN ISO 5817 in class qualities B and after penetration tested according to EN ISO 23277 in class qualities $2 x$. Results of testing are mentioned in Table 7 and also in Figure 6. Results were also well-documented by proper protocols and photo-documentation. Since acts about „lock circuit weld" without full penetration wasn't performed any X-ray testing.

Tab. 7 Results after visual and penetrant testing

\begin{tabular}{|l|l|l|}
\cline { 2 - 3 } \multicolumn{1}{c|}{} & Sample No. 1 & Sample No. 2 \\
\hline Visual testing & Acceptable. & Acceptable. \\
\hline $\begin{array}{l}\text { Penetrant tes- } \\
\text { ting }\end{array}$ & $\begin{array}{l}\text { Without indi- } \\
\text { cations. }\end{array}$ & $\begin{array}{l}\text { Without indi- } \\
\text { cations. }\end{array}$ \\
\hline
\end{tabular}

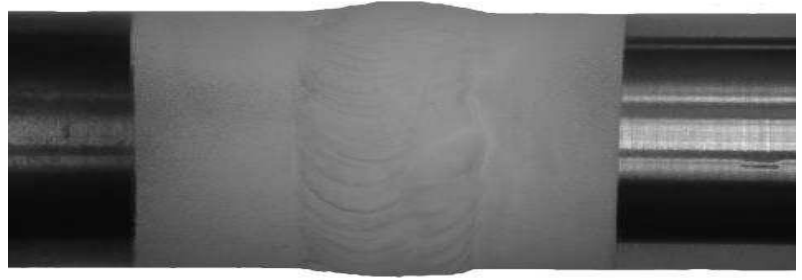

Fig. 6 Acceptable (without indications) photo after penetrant testing

\subsection{Metallographic evaluation of macrostructure}

The macroscopic testing was performed on both samples with acceptable results. Specific measured defects are mentioned in Table 8. The picture of the macrostructure is shown in Figure 7. Metering heat affected zone appearance to the character of a heterogeneous weld by GTAW welding technology wasn't affected.

Tab. 8 Evaluation of macrostructure

\begin{tabular}{|c|c|c|}
\hline Defect & $\begin{array}{c}\text { Values } \\
\text { sample } \\
\text { No. 1 }\end{array}$ & $\begin{array}{c}\text { Values } \\
\text { sample No. } \\
2\end{array}$ \\
\hline Crack & $0.0 \mathrm{~mm}$ & $0.0 \mathrm{~mm}$ \\
\hline Surface pore & $0.0 \mathrm{~mm}$ & $0.0 \mathrm{~mm}$ \\
\hline Cold joint & $0.0 \mathrm{~mm}$ & $0.0 \mathrm{~mm}$ \\
\hline $\begin{array}{c}\text { Unfused root } \\
\text { Cont. and discont. } \\
\text { undercut }\end{array}$ & $0.0 \mathrm{~mm}$ & $0.0 \mathrm{~mm}$ \\
\hline $\begin{array}{c}\text { Excessive } \\
\text { weld penetration }\end{array}$ & $1.9 \mathrm{~mm}$ & $1.8 \mathrm{~mm}$ \\
\hline $\begin{array}{c}\text { Abrupt weld } \\
\text { junction }\end{array}$ & $150^{\circ} 165^{\circ}$ & $165^{\circ} 150^{\circ}$ \\
\hline $\begin{array}{c}\text { Macro results } \\
\text { Acceptable }\end{array}$ & Acceptable \\
\hline
\end{tabular}

The evaluation of microstructure given known heterogenous weld microstructures welded by nickel alloy wasn't performed. 


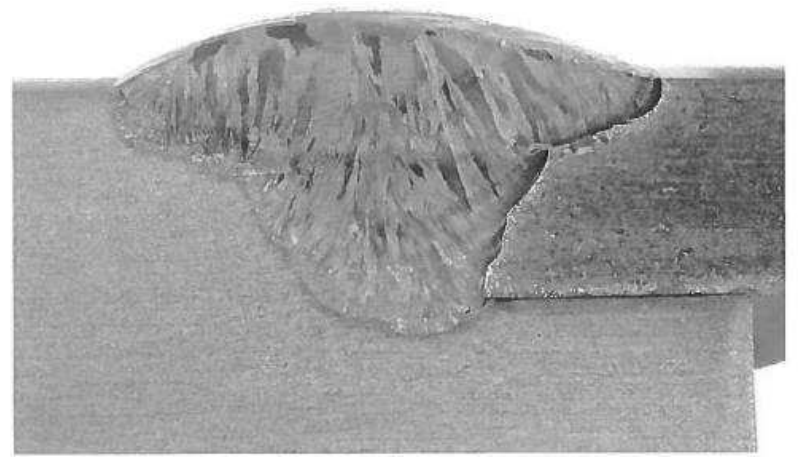

Fig. 7 Acceptable macro picture

\subsection{Hardness evaluation}

The hardness HV10 was measured according Figure 8 .

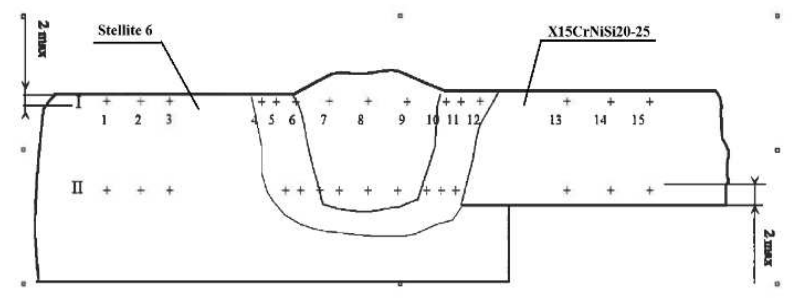

Fig. 8 Hardness HV10 measuring (picture with a puncture)

A measured values are evaluated in Graph 1.

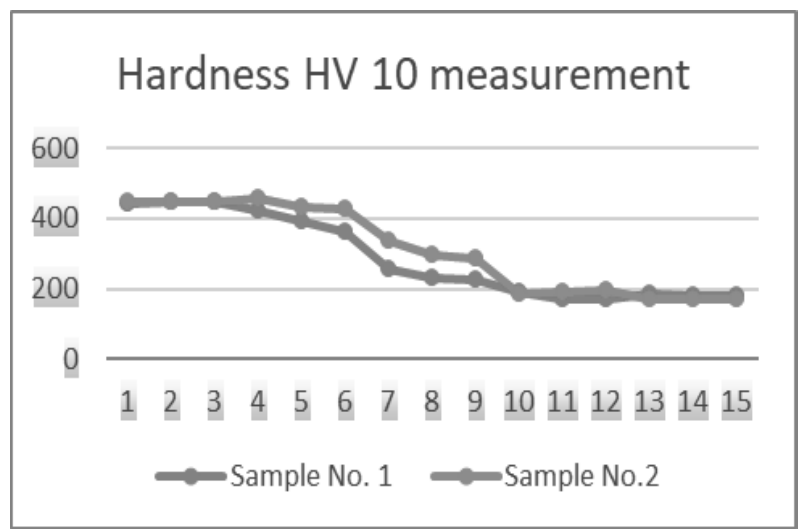

Graph 1 Measured hardness HV10 values for sample No.1 and No.2

From the Figure 8 and Graph 1 is evident, that the hardness of alloys Stellite 6 falling down, that is near to weld with nickel alloy $\mathrm{NiCr} 20 \mathrm{Mn} 3 \mathrm{Nb}$ filler material. Around near the heat resistant stainless steel X15CrNiSi20-25 hardness grown to heterogeneous weld. Is that so, because filler material is softer than Stellite 6 more softer closely material of heat-resistant stainless steel.

\section{Conclusions}

This article describes the experiment and evaluation of heterogeneous GTAW weld cobalt alloy and heat resistant stainless steel. The heat resistant stainless steel is regarding cracking factor predisposed to hot cracking. The cobalt alloy Stellite 6 is regarding different thermal cycles predisposed to cracking. It is possible expect that also heterogenous weld heat-resistant stainless steel and cobalt alloy Stellite 6 will be predisposed to cracking. These theory was not confirmed by this experiment (by visual and penetrant testing, by macrostructure and hardness evaluation). The article is specialized in checking possibilities of welding qualification specifications for these alloys on a specific single part, including checking mechanical properties and qualitative testing. From experiment results and also from performed evaluations were verified, that the welding qualification specification is possible to qualify according to standards EN ISO 15613. The cooperative company was therefore, recommended to carry out welding qualification specifications with expected suitable results.

\section{Acknowledgments}

Acknowledgments to cooperative company Seiko Flowcontrol, s.r.o., where were realized welding and VUT FSI Brno, Institute of Manufacturing Technology, Department of Forming, Welding and Surface Treatment, where were realized all evaluated exams and testing.

\section{References}

[1] HRIVÑÁK, I. (1988). Teória zuaritelnosti kovov a zliatin. Veda, Bratislava 1988. ISBN 80-2240016-5.

[2] Company literature Seiko Flowcontrol [online]. In:. 2019 [cit. 2019-02-17]. Available from: https://www.seiko-flowcontrol.com/seikobrochure.html

[3] SIGMUND, M. (2019). Plasma overlay welding of cobalt alloy. MM (Modern Macbinery) Science Journal, October 2019, 2019, page 2982-2986. ISSN 1803-1269, DOI 10.17973/MMSJ.2019_10_2018132

[4] LONGQUAN, S., NORTHWOOD, D.O., YHENGWANG, C. (1994). The properties of a wrought biomedical cobalt-chromium alloy, Journal of Material Science 29, 1994, pages 12331238.

[5] MORAVEC, J.; NOVAKOVA, I., SOBOTKA, J. (2018). Application Possibilities of Low-temperature Repairs by welding for Creep-resistance Material GX12crMoVNb9-1, Manufacturing Technology, December 2018, Vol. 18, No.6, page 980-985. ISSN 1213-2489. 
[6] ̌̌IHÁČEK, J.; SIGMUND, L. (2018). Production of Rolled Profile and Its Verification by Using Numerical Simulation. MM Science Journal, 2018, roč. 2018, č. 3, s. 2451-2454. ISSN: 1805-0476.

[7] AMBROŽ, O. (2001). Technologie svařování a zař̌zeni: ǔébni texty pro kuray sváréčskejch inženýri a technologù. Ostrava: ZEROSS, 2001. ISBN 8085771-81-0.
[8] GIESEN, K. (1964). Kobalt und seine Legierungen: physikalische und technologische Eigenschaften. Berlin: Springer-Verlag.

[9] FOLDYNA, V. (2001). Materiály a jejich svaritelnost: ǔ́ebni texty pro kurry svárééskeých in ženuýri a technologì. 2., upr. vyd. Ostrava: ZEROSS, 2001. ISBN 80-85771-85-3. 